\title{
Chemical Components and Biological Activity of Bidens Subalternans, B. Aurea (Astereaceae) and Zuccagnia Puntacta (Fabaceae)
}

\author{
C.A. Ortega, A.O.M. María and J.C. Gianello \\ Química Orgánica, Facultad de Química, Bioquímica y Farmacia, Universidad Nacional de San Luis. \\ Chacabuco y Pedernera. (5700), San Luis, Argentina \\ E-mail: jcgian@unsl.edu.ar
}

\begin{abstract}
The aim of this work was to evaluate the activity in the gastrointestinal tract of the several extracts and pure components isolated from Bidens species and Zuccagnia puntacta
\end{abstract}

\section{Introduction}

The interest in the phytochemical study of the species belonging to the genus Bidens (Astereaceae) derives from the fact that several of them, particularly those widely used in popular medicine, have been reported to have significant pharmacological and therapeutics properties [1-4]. Bidens subalternans D.C., popularly known as "amor seco" is an annual herb widely distributed in the northern and central parts of Argentina. Bidens aurea (Aiton) Sherff is a European herb widely distributed in the Mediterranean areas and commonly used as digestive and sedative. Zuccagnia puntacta Cav. (Fabaceae) is a monotypical specie distributed in dry areas of Argentina and Chile, popularly known as "jarilla macho" and used in popular medicine as rubefacient and anti-inflammatory.

The objetive of the present work was to assess the biological activity in the gastrointestinal tract of different extracts of these species and to identify and characterize secondary metabolites present in them.

\section{Experimental}

The methodology employed was the usual one in chemical-pharmacological investigations of natural product studies.

1. Determination of gastric cytoprotective activity of several isolated extracts and products in rats and/or mice.

The ulcer experimental model of gastric lesions were produced in according to the method of Robert et al. [5]. Absolute ethanol administered orally was employed as the necrotizing agent. The degree 
of erosion was assessed from a scoring system designed by Marazzi-Uberti and Turba [6]. The results were expressed in terms of an ulcer index (UI) or as cytoprotection percentage, according to Yamasaki et al. [7].

\section{Determination of small intestinal transit in mice}

The effect of samples on small intestinal transit was tested using Ueda et al. method [8]. The length traversed by the charcoal marker was calculated as a percentage of the intestine length.

The statistical significance of difference among means was assessed by Student's $t$-test or analysis of variance (ANOVA) with multiple comparison method by Tukey.

Chromatographic processing with different adsorbents of the chloroform soluble fractions obtained from the methanol extracts, allowed as to obtain the following compounds:

Bidens subalternans: maslinic acid, oleanolic acid, stigmasterol (I), stigmasterol-3-O- $\beta$-Dglucoside (II).

Bidens aurea: 2'-hydroxy-4,4'-dimetoxychalcone, (I) and (II).

Zuccagnia puntacta: 2',4'-dihydroxy-3'-metoxychalcone; 2',4'-dihydroxychalcone; 7hydroxyflavanone and 7-hydroxy-8-metoxyflavanone.

Identification was performed by uni- and bidimensional spectroscopic techniques ${ }^{1} \mathrm{H}-\mathrm{NMR}$ y ${ }^{13} \mathrm{C}$ NMR, ME and GC-ME combined techniques.

\section{Results and Discussion}

The results obtained are reported in the tables below.

\begin{tabular}{|c|c|c|}
\hline $\begin{array}{l}\text { Treatment pre- } \\
\text { vious to } \mathrm{EtOH}\end{array}$ & $\begin{array}{l}\text { Ulcer Index } \\
(\mathrm{X} \pm \mathrm{SEM})\end{array}$ & $\begin{array}{l}\text { Damage } \\
\text { inhibition }\end{array}$ \\
\hline $\begin{array}{l}\mathrm{MeOH} \text { ext. of } \\
\text { B. aurea }\end{array}$ & $3,87 \pm 0,12 *$ & $20 \%$ \\
\hline $\begin{array}{l}\mathrm{Cl}_{3} \mathrm{CH} \text { ext. of } \\
\text { B. aurea }\end{array}$ & $2,83 \pm 0,33 *$ & $41 \%$ \\
\hline $\begin{array}{l}\text { MeOH ext. of } \\
\text { B. subalterna }\end{array}$ & $3,50 \pm 0,20^{*}$ & $27 \%$ \\
\hline $\begin{array}{l}\text { MeOH ext. of } \\
\text { Z. punctata }\end{array}$ & $0,75 \pm 0,25 * * * a$ & $84 \%$ \\
\hline $\begin{array}{l}\text { Z.punctata aque- } \\
\text { ous infusion }\end{array}$ & $2,75 \pm 0,43 * *^{b}$ & $43 \%$ \\
\hline $\begin{array}{l}\text { 2',4'-diOH-3'- } \\
\text { metoxychalcone }\end{array}$ & $3,6 \pm 0,54 * *^{\mathrm{a}}$ & $25 \%$ \\
\hline $\begin{array}{l}\text { 2',4'-diOH- } \\
\text { chalcone }\end{array}$ & $1,75 \pm 0,25 * * * b$ & $63 \%$ \\
\hline vehicle & $4,83 \pm 0,16$ & -- \\
\hline
\end{tabular}




\begin{tabular}{|l|c|}
\hline Treatment previous to C & $\begin{array}{c}\text { Intestinal transit } \\
(\%)(\mathrm{X} \pm \mathrm{SEM})\end{array}$ \\
\hline B. aurea extract & $45,57 \pm 3,49^{* *}$ \\
\hline B. subalterna extract & $52,90 \pm 2,98$ \\
\hline MeOH ext. of $Z$. punctata & $35,61 \pm 2,97 * * *^{\mathrm{a}}$ \\
\hline Z. punctata aqueous infusion & $46,82 \pm 2,04^{* \mathrm{~b}}$ \\
\hline 2',4'-diOH-3'-metoxychalcone & $47,17 \pm 1,85^{*} *^{\mathrm{c}}$ \\
\hline 2',4'-diOH-chalcone & $44,82 \pm 2,51^{*} * *^{\mathrm{c}}$ \\
\hline vehicle & $57,86 \pm 3,09$ \\
\hline
\end{tabular}

$* \mathrm{p}<0,05 ; * * \mathrm{p}<0.02 ; * * * \mathrm{p}<0.001$ vs. controls, respectively; $\mathrm{a} \neq \mathrm{b} \quad(\mathrm{p}<0.01) \quad$ (Student's $t$-test or analysis of variance (ANOVA) with multiple comparison method by Tukey.

The higher activity of the chloroform extracts compared to the methanol extracts ones or aqueous infusions can be accounted for the higher concentration of active compounds in extracts.

\section{References and Notes}

1. Redl, K.; Brew, W.; Davis, B.; Bunes. Planta Medica 1994, 60, 58.

2. de la Lastra, C.A.; Martín, M. J.; La Casa, C.; Motilva, V. J. of Ethnopharm. 1994, 42, 161.

3. Ortega, C.A.; Rotelli, A.E.; Gianello, J.C. Planta Medica 1998, 778.

4. Pederiva, R.; Giordano, O.S. Phytochemistry 1984, 23,1340.

5. Robert, A.; Nezzamis, J.E.; Lancaster, C. Gastroenterology 1979, 77,433.

6. Marazzi-Uberti, E.; Turba, C. J. Nat. Prod. 1990, 53(4), 803.

7. Yamasaki, K.; Ishiyama, H. et al. Jpn. J. Pharmacol. 1989, 49, 441.

8. Ueda, M.; Matsuda, S. et al. Jpn. J. S. Muscle Res. 1969, 5, 108. 